$\underline{\text { Review Article }}$

\title{
ARTABOTRYS HEXAPETALUS (L. F.) BHANDARI: A PLANT WITH ENORMOUS BIOMEDICAL POTENTIAL
}

\author{
ABHIJEET V. PURI \\ Department of Pharmacognosy, St. John Institute of Pharmacy and Research, Vevoor, Manor Road, Palghar (E), Dist-Palghar, 401404, \\ Maharashtra, India \\ Email: avpuri@rediffmail.com \\ Received: 06 Apr 2020, Revised and Accepted: 04 May 2020
}

\begin{abstract}
This review is intended to investigate the published report regarding phytochemical, ethnomedicinal, and pharmacological activities and put forth the therapeutic potential of Artabotrys hexapetalus (L. f.) Bhandari. (A. hexapetalus). It belongs to the family Annonaceae, one of the therapeutically important plants, broadly distributed throughout the world. An extensive review of the literature available in various recognized databases including logical writing and scientific literature, search engines such as Springerlink, ScienceDirect, SciFinder, PubMed, Scopus, Google Scholar, and BioMed Central as well as relevant books, websites, scientific publications, and dissertations were utilized as a source of information that provided an up-to-date review. Phytochemical profiling of these species revealed the presence of some imperative phytochemicals alkaloids, terpenoids, anthraquinones, butyrolactones, flavonoids, neolignans, phenolic compounds, and leucoanthocyanins as the basis of its valuable therapeutic properties. The other imperative phytoconstituents which contribute to the therapeutic properties are isoamericanin $\mathrm{A}$, isoamericanol, americanin, artabotricinol and artabotriol, $\beta$-unsaturated- $\beta$-butyrolactones, arapetaloside taxifolin, apigenin-7-0-apiosylglucoside, glucoluteolin, and artabotrine. The pharmacological activities exhibited by Artabotrys hexapetalus as antimicrobial, antileishmanial, antioxidant, antifungal, antifertility, and anthelmintic properties are attributed to the presence of valuable bioactive phytoconstituents. Considering these facts an effort was made to present a comprehensive review enlightening the taxonomical, phytochemical, and pharmacological activities of plant Artabotrys hexapetalus. Future research can be directed to an extensive investigation about phytochemistry, clinical trials, pharmacokinetics, and acquiring safety data to add new dimensions to the therapeutic utilization of Artabotrys hexapetalus and other Artabotrys species.
\end{abstract}

Keywords: Artabotrys hexapetalus, Annonaceae, Pharmacological, Phytochemicals

() 2020 The Authors. Published by Innovare Academic Sciences Pvt Ltd. This is an open access article under the CC BY license (http://creativecommons.org/licenses/by/4.0/) DOI: http://dx.doi.org/10.22159/ijpps.2020v12i6.37778. Journal homepage: https://innovareacademics.in/journals/index.php/ijpps

\section{INTRODUCTION}

Artabotrys is a genus of woody trees, shrubs, and vines comprising about 130 genera and 2,300 species, which is distributed mainly in tropical and subtropical regions of the world, especially tropical Africa and Eastern Asia and the Indomalayan region [1, 2]. Plants of Artabotrys genus are climbing herbs bearing recurved hooks borne on lateral branches and scandent shrubs are one of the largest genera of the custard-apple family [3]. Artabotrys hexapetalus (L. f.) (A. hexapetalus) Bhandari generally described as a folk drug that has a wide range of medicinal uses belonging to family Annonaceae. The family includes trees, shrubs, and lianas, found in almost all vegetation types. It is generally considered to be a natural family and one of the six members of Magnoliales [4]. It is an ornamental, medium-sized woody climber that produces aromatic flowers with fragrance. A. hexapetalus is native to India and widely distributed in the southern part of China, and is used in traditional Chinese medicine for the treatment of malaria [5]. It is a medium-sized climbing shrub, largely cultivated in India. Leaves are oblong, lanceolate, and glabrous. Flowers solitary or paired, often fragrant, usually on woody, hooked recurved branches (Peduncles) [6]. It is widely distributed throughout the southern part of China and also in the southern part of Asia. As a Chinese traditional folk medicine, its roots and fruits are used for treating malaria and scrofula, respectively [7]. The flower is acrid, bitter; useful in vomiting, diseases of the blood and the heart, leucoderma, headache. A decoction of leaves is given for cholera. Phytochemically it contains alkaloids, anthraquinones, butyrolactones, flavonoids, neolignans, phenolic compounds, leucoanthocyanins, terpenoids, and volatile oils [8-10]. Many phytochemicals in the form of flavonoids of $A$. hexapetalus possibly be modified or used as "lead" for developing more effective drug molecules. Hence, extensive pharmacological and phytochemical screening, together with the pharmacokinetic and toxicological assay can be aimed at future investigations. Hence an attempt is made to highlight selected phytochemical and biomedical potentials of $A$. hexapetalus species in this review.
Introduction to Artabotrys hexapetalus (L. f.) Bhandari

Taxonomical classification [11]

Domain: Eukaryota

Kingdom: Plantae

Subkingdom: Tracheophytes

Division: Magnoliophyta

Subphylum: Angiosperms

Class: Magnoliopsida-Dicotyledons

Subclass: Magnoliidae

Order: Magnoliales

Family: Annonaceae

SubFamily: Annonoideae

Genus: Artabotrys

Species: Artabotrys hexapetalus

Common Name: Ylang-Ylang, Hari Chafa

Vernacular names [12]

Sanskrit: Harachampaka.

Tamil: Manoranjidam.

Telugu: Manoranjidamu.

Marathi: Vilayati Champa.

Genus: Artabotrys

Species: Hexapetalus 
Synomym: Hornschuchiaceae

\section{Etymology}

A. hexapetalus Indochina: Day cong chua.

Artabotrys $=$ arta + botrys $($ artao $=$ Support, botrys $=$ bunch of grapes $)$ Hexapetalus $=6$ petals

A plant with 6 petelled flower and fruits resembles a bunch of grapes [13].

\section{Geographic distribution of $A$. hexapetalus}

A. hexapetalus probably native to South India and largely cultivated in India, Sri-Lanka, Burma, Southern China, and Taiwan. In different parts of the world, it is largely known as an ornamental plant. Within India, it is indigenous to South India and very commonly cultivated in gardens throughout the country for its fragrant flowers. Plant is propagated through stem cutting and seed. Group of fruits (usually 6) grow together at the end of the long peduncle [14].

\section{Characteristics of plant $A$. hexapetalus}

The plant is a climber with lateral branches straight, lenticellate, glabrous, dark brown when dry, young twigs sparsely pubescent shown in fig. 1.

\section{Leaves}

The leaves are simple, alternate, petiolated (3-8 $\mathrm{mm})$, exstipulate, and distichously arranged. They are thinly pubescent; oblonglanceolate 6-10 mm long, shortly acuminate, elliptic, glabrous on both surfaces with a thinly coriaceous blade, and the base is acute cuneate. The colour of the leaves is pale green when dry. The midrib of the leaf is flat on the upper epidermis and raised at the lower epidermis with lateral anastomosing veins flat on both surfaces $[15,16]$.

\section{Inflorescence}

It has a flat peduncle, solitary or in pairs that are sparsely pubescent with two branches; 1-2 flowers; bract elliptic to oblong and bud broadly ovoid.

\section{Flowers}

The flowers are bisexual and actinomorphic, possessing 3 whorls of perianth with 3 segments in each whorl. Entire parts of floral are distinct, yellow, solitary or in pairs, $3.2-3.8 \mathrm{~cm}$ long, pedicels $15-20 \mathrm{~mm}$ long, sepals are $6 \mathrm{~cm}$ long that erect to reflexed sparsely pubescent. Flowers are thinly fleshy, ovate, with acute apex and pubescent. The petals are fleshy, connate below, tips reflexed petals are lanceolate above the saccate base, clothed with apprised silky hairs. Inner petals are narrower, flat, 20-30 x 3-6 mm; torus convex; stamen are oblong. Apical possess a cylindrical carpels prolongation flat, obovoid, glabrous with 2 $3 \mathrm{~cm}$ in diameter. The stamens are very short and tightly packed generally fertile with central anther portion, a distal pad of fleshy connective tissue, and a short fleshy basal portion $[17,18]$.

\section{Fruit}

Appeared berries, obovoid to ellipsoid, $3.5-4$ x $1.5 \mathrm{~cm}$, apex mucronate; stalk $20 \times 1.5 \mathrm{~mm}$, sparsely pubescent. It bears berry-like fruits but sometimes forms multiple fruits like the custard apple [19].

\section{Seed}

Two large, ellipsoid oblong little flattened, deeply grooved on one side, more than $13 \mathrm{~mm}$ long. Sectioned seeds reveal channels or partitions in the ruminate endosperm [20].

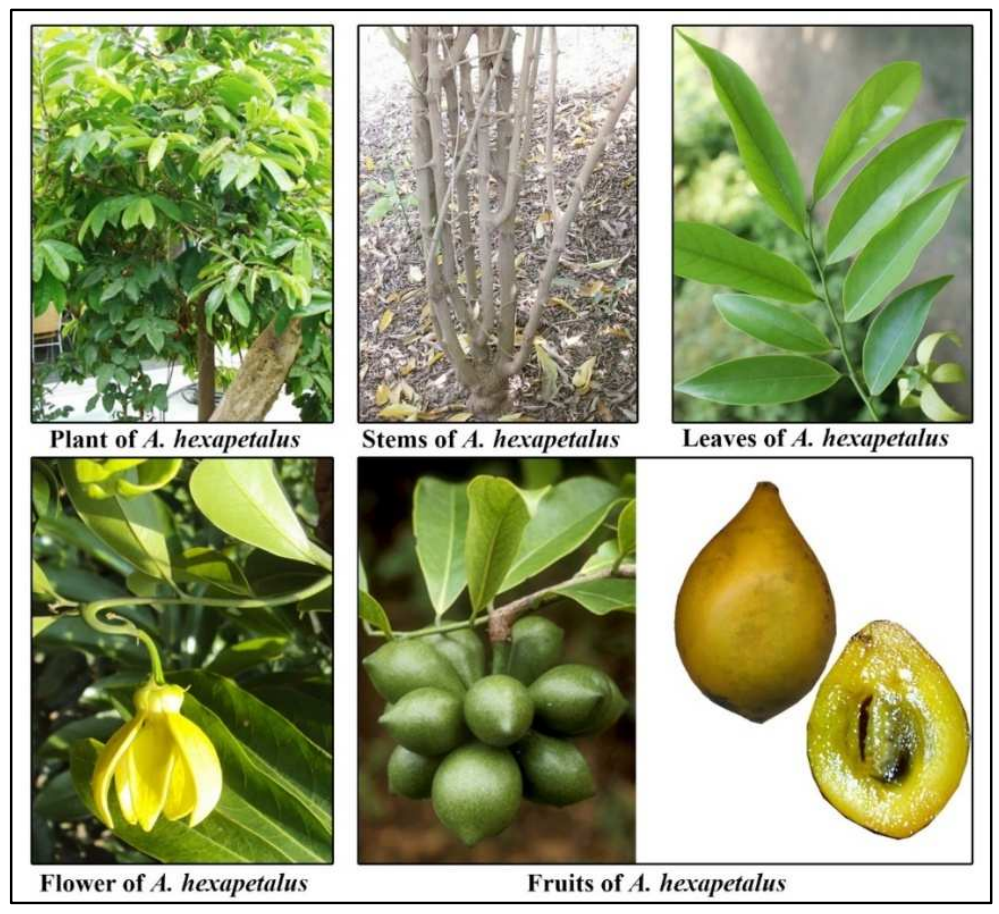

Fig. 1: Morphology of the A. hexapetalus plant

\section{Traditional uses of $A$. hexapetalus}

Medicinal plants and traditional systems of medication is been continuously allied as the backbone of these systems. India has an ironic natural heritage of traditional systems of medicine. These traditional systems of medications with the perceptions of safety, efficacy, and quality will urge to protect the customary heritage [21]. The flowers of $A$. hexapetalus are tonic and stimulant. The fruits and the bark are used to treat fever, diarrhea, skin diseases, wounds, ulcers, inflammation, cough, asthma, and bronchitis. The leaves extract has antibacterial, antifertility, and antifungal activity [22]. The pulp of ripened fruits has been used traditionally in some parts of Assam for the fungal infections in the domestic animals the tribes of Malay Archipelago use a decoction of leaf for treatment of Cholera. Roots of this plant are used to treat Malaria according to Chinese traditional systems of medicine. The volatile oil from the flower in the Unani system of medicine is used in aromatherapy [23, 24]. In Ayurveda and Siddha systems of medicines flowers used as tonic 
and stimulant. Fruit and bark are used to treat fever, diarrhea, flatulence, colic, constipation, skin disorders, wound healing, cough, and bronchial asthma. The decoction of leaves used as an antimicrobial, antifertility, muscle relaxant, and cardiac stimulant [25]. Flowers used as a flavoring in tea Southern India; Sri Lanka Used in perfumery as the source of essential oils. In Salem, Tamil Nadu, Southern India used in the preparation of stimulating tea-like beverages. In Java, Indonesia, Philippines, Southern China, India whole plant is used as an ornamental plant and for screen planting in large gardens. In traditional Chinese systems of medicine prescribed for the treatment of malaria and scrofula [26-28].

\section{Phytochemical composition of $A$. hexapetalus}

The literature proposes that $A$. hexapetalus possess important bioactive compounds, as shown in fig. 2 .

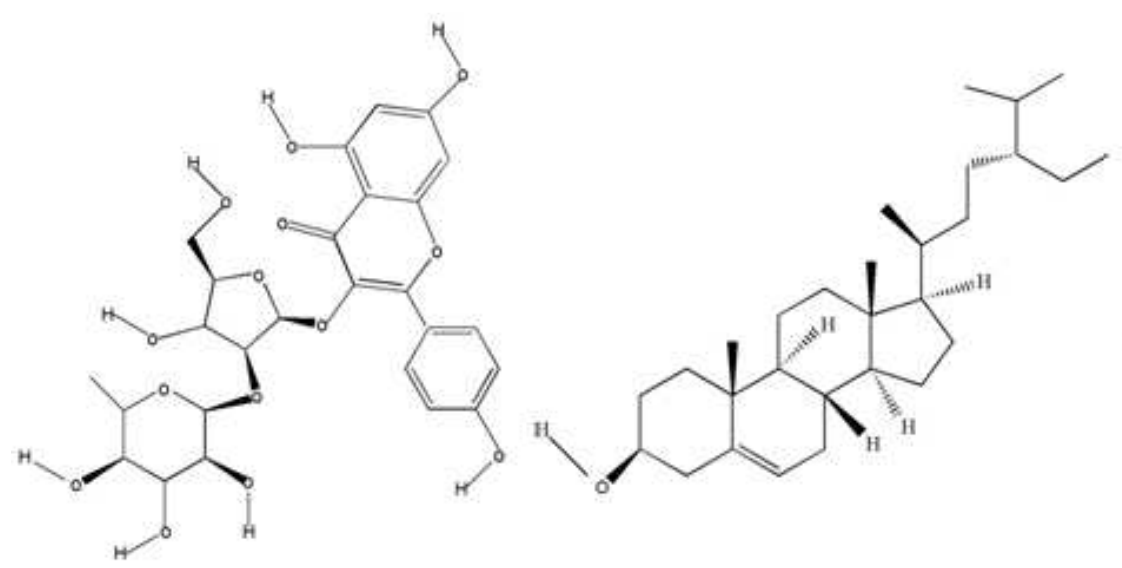

Artabotryside $\beta$-sitosterol<smiles>COc1ccc([C@@H]2Oc3cc(O)cc(OP)c3C(=O)[C@@H]2CN)cc1OC</smiles>

Taxifoline<smiles>COc1ccc2c(c1O)-c1c(OC)ccc3c1[C@@H](C2)NCC3</smiles>

Artabotrine<smiles>O=C/C=C/c1ccc2c(c1)O[C@H](CO)[C@H](c1ccc(O)c(O)c1)O2</smiles>

Americanin<smiles>COc1cc(C2Oc3cc(/C=C/C=O)ccc3OC2CO)ccc1O</smiles>

Isoamericanin<smiles>COCC(N)=C(P)c1ccc2c(c1)OC(c1ccc(OC)c(OC)c1)C(CO)O2</smiles>

Isoamericanol<smiles>C[C@H](O)CC[C@H]1[C@@H](C)C[C@H](C)CC1(C)C</smiles>

Megastigmane<smiles>C=C(CO)[C@@H](O)C(C)O</smiles>

Artabotriol

Fig. 2: Phytoconstituents of $A$. hexapetalus

Interestingly almost all parts of the $A$. hexapetalus species have been explored for phytochemical analysis and various phytoconstituents are isolated to date. Various important phytoconstituents have been reported are 4-neolignan, namely isoamericanin $\mathrm{A}$, isoamericanol $\mathrm{A}$, americanin B and artabotricinol a semi terpenoid: (R) artabotriol. It contains $\beta$-unsaturated- $\beta$-butyrolactones. Flavonol glycosides namely arapetaloside A and B are reported, Flavonoids: taxifolin, apigenin-7-0apiosylglucoside, and glucoluteolin. Alkaloid: artabotrine [29] table 1. 
Table 1: Chemical constituents of $A$. hexapetalus

\begin{tabular}{|c|c|c|c|c|}
\hline S. No. & Phytochemical & & Plant part & Reference \\
\hline 1. & 4-neolignan & $\begin{array}{l}\text { Isoamericanin A, Isoamericanol A, } \\
\text { Americanin B and Artabotricinol }\end{array}$ & Seeds & $\mathrm{Yu}$ J et al. [30] \\
\hline 2. & Semi-terpenoids & Artabotriol & Seeds & G. Yu et. al. [32] \\
\hline 3. & Lactones. & $\beta$-unsaturated- $\beta$-butyrolactones. & Ariel parts & Wong et al.[31] \\
\hline 4. & Flavonol glycosides & Arapetraloside A and B & Roots & $\begin{array}{l}\text { Tong-mei et al. [34] } \\
\text { Singh et al. [39] }\end{array}$ \\
\hline 5. & Flavonoids & $\begin{array}{l}\text { Taxifolin, apegenin-7-0-Apiosylglucoside, } \\
\text { and glucolutioline }\end{array}$ & Roots, Leaves & $\begin{array}{l}\text { Li T [33] } \\
\text { Somanawat et al.[35] }\end{array}$ \\
\hline 6. & Alkaloid & Artabotrine hexapetalines A and B & Roots Stem & QiZhou et al.[31] \\
\hline 7. & Organic acid & Succinic, Fumaric acid & Fruits & Yao Xue et al. [30] \\
\hline 8. & Sterols & $\beta$-sitosterol, Daucosterol & Seeds & G. Yu et. al[32] \\
\hline 9. & Sesquiterpenoids & $\beta$-caryophyllene, Caryophyllene oxide & Flowers, Roots & $\begin{array}{l}\text { Feng-Min Xi et al. [36] } \\
\text { Phan et al. [40] }\end{array}$ \\
\hline
\end{tabular}

A. hexapetalus.: Artabotys hexapetalus (L. f.) Bhandari

Yu J et al. 2002 have isolated four neo-lignans-isoamericanin A, isoamericanol A, americanin B, and artbotrycinol and a hemiterpenoid: (R)-artabotriol and other compounds from the seeds of $A$. hexapetalus and reported the presence palmitic acid, $\beta$ sitosterol, and daucosterol [30]. Wong $\mathrm{H}$ et al. 2002 have reported that the dichloromethane extract of the aerial parts of $A$. hexapetalus contains $\beta$-methoxy- $\gamma$-methylene- $\alpha, \beta$-unsaturated- $\gamma$-butyrolactones which are anticipated to be derived from a C-18 unsaturated fatty acid [31]. Yu J et al. 2001 have studied the chemical constituents of the seeds of $A$. hexapetalus. Eight compounds were isolated and identified as four Neolignans-isoamericanin A, isoamericanol A, americanin B, and artbotrycinol, a semiterpenoid: (R)-artabotriol and others [32]. Li $\mathrm{T}$ et al. 1997 reported the isolation of various constituents from A. hexapetalus leaves. They isolated two new flavonol glycosides derivatives of artabotryside and three known flavonoids: taxifolin, 7-0-glucoluteolin, apigenin glycoside, and two organic acids as succinic and fumaric acid. Based on spectral analysis structures elucidated were quercetin and kaempferol [33]. Tong-Mei Li et al. 1997 reported the isolation of two novel flavonol glycosides from the leaves of $A$. hexapetalus. Isolated compounds were named as arapetaloside A and B. Additionally taxifolin, apigenin glucoside, and glucoluteolin flavonoids were also isolated [34]. Somanawat J et al. 2012 isolated and identified a megastigmane glucoside along with four flavonoid glycosides from the leaves of $A$. hexapetalus. They identified these compounds by applying various spectroscopic techniques. Also for the first time occurrence of megastigmane glucoside and quercetin triglycoside in this plant is being reported [35]. Feng-Min Xi et al. 2017 isolated seven pairs of sesquiterpene from the roots of $A$. hexapetalus identified as a new peroxy-bridge sesquiterpene and peroxy-bridge norsesquiterpene with five known compounds. Their structures of compounds were confirmed by elucidation based on spectroscopic characterization. Seven pairs of stereoisomers were confirmed by chiral HPLC [36]. Qi Zhou et al. 2015 reported the isolation of two new alkaloids as benzylisoquinoline derivatives named hexapetalines $\mathrm{A}$ and $\mathrm{B}$ from the stems of $A$. hexapetalus. The structures of hexapetalines were elucidated by using extensive spectroscopic methods and compounds were identified by comparisons with the literature [37].
Yao Xue et al. 1998 have isolated two new flavonol glycosides, artabotryside A and B, three known flavonoids: taxifolin, 7-0glucoluteolin, apigenin-7-0-apiosyl glycoside, and succinic and fumaric acid from the leaves of $A$. hexapetalus. The structures of compound artabotryside and its derivative were elucidated based on spectral analysis. For the first time, compound quercetin-3-0-alphaL-rhamnopyranosyl (1->2)-alpha-L-arabinofuranoside and kaempferol-3-0-alpha-L-rhamnopyranosyl (1->2)-alpha-Larabinofuranoside were isolated [38]. Singh A et al. 1997 have reported the isolation of the flavonol glycosides-quercetin, quercetin 3-0-glucoside, 3-0-arabinoside, and 3-0-galactoside along with kaempferol, myricetin, and gallic acid from the leaves of $A$. hexapetalus [39]. Phan, G et al. 2007 reported extraction, identification, and analysis of essential oil from the flower of $A$. hexapetalus. Compounds were analyzed by using GC and GC/MS spectroscopic techniques. Twenty-six components of the oil that were identified as sesquiterpene hydrocarbons and oxygenated sesquiterpenoids, $\beta$-caryophyllene, and caryophyllene oxide [40]. Mahidol C et al. 2005. Investigated compositions of the essential oils from flowers of $A$. hexapetalus. the flowers were subjected to hydrodistillation, solvent extraction, solid-phase microextraction, and simple headspace solvent-trapping technique. By hydrodistillation, thirty-one components and five unidentified ones were identified together as $\beta$-caryophyllene, $\beta$-gurjunene, and globulol. Employing solvent extraction method thirty-one components were identified as 3-methyl butanol, 2-methylbutanol, ethyl butanoate, isopentyl acetate, 2-methyl butyl acetate, limonene, linalool, and two unidentified components. The other two unconventional extraction methods were employed as simple headspace solvent-trapping techniques. Using this method, seventeen components were identified as ethyl acetate, ethyl isobutanoate, isobutyl acetate, and ethyl butanoate. Employing the Solid-phase microextraction technique the headspace vapor of the fresh flowers was absorbed on the viscous liquid, polydimethylsiloxane (PDMS), and injected directly into the GC-MS. By using this method Thirtynine components were identified with three unidentified ones were Ethyl acetate, ethyl isobutanoate, isobutyl acetate, ethyl 2-methyl butanoate, ethyl isovalerate, ethyl 3-methyl-2butenoate, isobutyl isovalerate, and $\beta$-caryophyllene [41].

Table 2: Biological activities of $A$. hexapetalus

\begin{tabular}{|c|c|c|c|}
\hline S. No. & Part of plant & Activity reported & Reference \\
\hline 1. & Leaf & Antioxidant Activity: & Satya et. al [58] \\
\hline 2. & & Antifertility Activity & Karthik et al. [62] \\
\hline \multirow[t]{2}{*}{3.} & & Hepatoprotective activity & Veena et al. [63] \\
\hline & & Antibacterial and Antifungal activity & Grainge et al. [ 54] \\
\hline 4. & Bark & Anthelmintic and Cytotoxic activities & Morshed et al. [64] \\
\hline 5. & & Antimicrobial activity & Shankar et al. [52] \\
\hline 6. & & Antileishmanial activity & Bajaj et al. [56] \\
\hline 7. & & Mosquito repellent activity & Rajabu et al. [62] \\
\hline 8. & Root & Antimalarial & Wijesekera [66] \\
\hline 9. & Flower & Antipyretic & Rahini et al. [65] \\
\hline
\end{tabular}

A. hexapetalus.: Artabotys hexapetalus (L. f.) Bhandari. 


\section{Biological and pharmacological activities of $A$. hexapetalus}

Herbal drugs have been playing a substantial role throughout the world in treating and preventing several diseases [42]. The essential oil of this plant has shown excellent antihelmintic property against tapeworms, earthworms, and roundworms [43]. Fruits of this plant are recoded as containing fixed and volatile oil, glycosides, and resins. Extracts are reported to show hypotensive and spasmogenic, as well as cardiac stimulating effects on some animals and a cardiac depressant on others [44]. Ethanolic and benzene extracts of leaves have shown irregular oestrus cycle in albino rats. Also used as a remedy to treat abdominal and kidney pains [45]. Decoction used in the treatment of cholera. It is used as a cardiotonic, cardiac stimulant, muscle relaxant, and uterine stimulant [46-51] (table 2).

\section{Antimicrobial activity}

Shankar P, et al. 2011 investigated acetone and ethanolic extracts of leaves of $A$. hexapetalus for antibacterial efficacy. The phytochemical analysis confirmed the presence of flavonoids, alkaloids, tannin, sterols, and terpenoids. Ethanolic extract showed significant antibacterial activity against E. coli, Bacillus subtilis, and Salmonella typhi. Acetone extract showed the maximum zone of inhibition against Staphylococcus aureus [52]. Sowjanya K, et al. 2013 reported antibacterial and antifungal activity of methanolic extracts of $A$. hexapetalus leaves. This antimicrobial activity was carried out using the agar well diffusion method. Different concentration of extracts $(25-100 \mu \mathrm{g} / \mathrm{ml})$ was tested against Salmonella typhi, Streptococcus entericus, lactobacillus casei, streptococcus mutans, Escherichia coli, Pseudomonas aeruginosa, Staphylococcus aureus, bacillus megaterium, Enterococcus faecalis Xanthomonas campestris Candida albicans, Aspergillus niger, Rhizopus oryzae and Candida rogasa. The results proved noteworthy microbial inhibition calculated from zones of growth inhibition [53]. Grainge M, et al. 1987 in this investigation tested leaf extracts of $A$. hexapetalus against Xanthomonas Campestris and Drechslera oryzae (Cochliobolus miyabeanus) and 10 other bacterial strains. The leaf extracts showed inhibition in the growth of X. campestris $p v$ and campestris [54]. Haseena S, et al. 2019 reported the green synthesis of $\mathrm{CuO}$ nanoparticles using $A$. hexapetalus extract by co-precipitation method. The antibacterial ability of $\mathrm{CuO}$ nanoparticles was determined against gram-negative E. coli pathogen by the agar-agar diffusion method. Results revealed that $\mathrm{CuO}$ nanoparticles showed significant antibacterial activity against gram-positive $E$. coli strain [55].

\section{Antileishmanial activity}

Bajaj S, et al. 2018 evaluated the in vitro antileishmanial activity of extracts of $A$. hexapetalus against the Leishmania donovani (L. donovani) promastigotes. The plant extracts inhibited the growth of L. donovani in vitro after $24,48,72$, and $96 \mathrm{~h}$ of incubation and had $50 \%$ inhibitory concentration (IC50). The lowermost concentration of extract showed inhibition of growth of $L$. donovani parasites it was measured as the maximum inhibitory concentration. This indicated after incubation at 24 and $48 \mathrm{~h}$. all extracts showed antileishmanial activity in a dose-dependent mode [56].

\section{Antioxidant activity}

Manjula M, et al. 2011 reported screening of antioxidant and antimicrobial activity of $A$. hexapetalus flower extracts. 2,2,1diphenyl-1-picrylhydrazyl (DPPH) and reducing power method was utilized in the screening of antioxidant activity Results indicated reducing the power of extracts increased with increase in the concentration of extracts. DPPH free radical-scavenging of chloroform, methanol, aqueous extracts, and Gallic acid as standard with half-maximal inhibitory concentration $\mathrm{IC}_{50}$ values at the concentration range of $50-250 \mu \mathrm{g} / \mathrm{ml}$ were determined as $378.73 \mu \mathrm{g} / \mathrm{ml}, 72.0 \mu \mathrm{g} / \mathrm{ml}, 118.49 \mu \mathrm{g} / \mathrm{ml}$ and $68.75 \mu \mathrm{g} / \mathrm{ml}$ respectively [57]. Satya K, et al. 2017 determined free radical scavenging activity of methanol extract of $A$. hexapetalus utilizing ascorbic acid as standard antioxidant. DPPH method was used for screening of antioxidant activity. A. hexapetalus extracts showed a $52.99 \%$ scavenging activity in the DPPH assay [58]. Rahini D, et al. 2014 carried out in vitro free radical scavenging assays of $A$. hexapetalus flower extract. This assay was performed by determination of total antioxidant capacity, reducing ability Nitric oxide radical, and scavenging of hydrogen peroxide. A. hexapetalus flower extract effectively scavenged free radicals at all different concentrations and showed its potent antioxidant activity [59]. Bollapragada M, et al. 2018 determined in vitro antioxidant activity of methanolic extract of $A$. hexapetalus leaves. The antioxidant assay was determined using DPPH, ferric reducing antioxidant power, and total antioxidant capacity. The activity of methanolic extract at lower concentrations $10-50 \mu \mathrm{g} / \mathrm{ml}$. IC 50 values were $33.95 \mu \mathrm{g} / \mathrm{ml}$ in comparison to that of standard ascorbic acid $33.2 \mu \mathrm{g} / \mathrm{ml}$. The results demonstrated that the extract of $A$. hexapetalus had a significantly higher $(\mathrm{p}<0.05)$ value. Hydroxyl radical scavenging activity of methanolic extract of $A$. hexapetalus showed $200.3 \pm 3.11 \mu \mathrm{g} / \mathrm{ml} \mathrm{IC}_{50}$ value [60].

\section{Mosquito repellent activity}

Rajabu A, et al. 2014 investigated mosquito repellent activity of their essential oils of leaves and stem bark of $A$. hexapetalus. The composition of oil from the stem bark and leaves showed both $\beta$ caryophyllene oxide and 11-hexadcyn-1-ol as the main components. Essential oil from the leaves of $A$. hexapetalus displayed strong activity with Repellent concentrations ( $\mathrm{RC}_{50}$ ) values $1.81 \times 10-5$ $\mathrm{mg} / \mathrm{cm}^{2}$ and $2.79 \times 10-5 \mathrm{mg} / \mathrm{cm}^{2}$. Against mosquitoes female Anopheles gambiae s. $s$. The repellency activity of essential oil in comparison to standard citronella oil used $($ RC50 $=4.1 \times 10-6$ $\mathrm{mg} / \mathrm{cm} 2$ ) was found to be moderate [61].

\section{Anti-fertility activity}

Karthik Y, et al. 2012 evaluated the antifertility activity of hydroalcoholic extract of $A$. hexapetalus leaves in vivo on male Wistar rats and female Sprague Dawley rats and rabbits. In this study, male Wistar rats were orally fed with hydroalcoholic extract at a concentration of $200,400,600 \mathrm{mg} / \mathrm{kg}$. p. o, for $45 \mathrm{~d}$. This effect of the extract on reproductive organs, sperm count, serum testosterone, testicular cholesterol, and alkaline phosphates levels was noted and changes in testicular histology were compared with the control rats. Progestogenic activity assay was determined by pregnancy maintenance test in female Sprague Dawley rats. The result showed a decrease in weight of testis, seminal vesicles and sperm count, serum testosterone testicular cholesterol and alkaline phosphates level and the histological examination of testis demonstrated that decrease in the diameter of seminiferous tubule server hypercellularity of Leydig cells. The Pregnancy maintenance assay displayed non-progestogenic, progestational, or antiprogestational activities [62].

\section{Hepatoprotective activity}

Veena R, et al. 2016 screened the alcoholic extract of $A$. hexapetalus for in vivo hepatoprotective activity in rats, which were intoxicated by paracetamol. The hepatoprotective activity and oxidative stress of $A$. hexapetalus were determined using parameters like serum enzyme levels like SGOT, SGPT, ALP, ACP, Total Bilirubin, Direct Bilirubin, SOD, GSH, Vitamin C and catalase levels of the animals treated with hepato-toxic paracetamol. The alcoholic extract of $A$. hexapetalus overturned the hepatotoxicity that was induced by paracetamol in the rats, indicating their hepatoprotective action. This histopathological studies reveled structural damage occurred due to paracetamol, which was further supported by the DNA fragmentation studies that showed the absence of fragmentation of DNA in alcoholic extract-treated groups, indicating the hepatoprotective activity of $A$. hexapetalus [63].

\section{Anthelmintic activity}

Niaz M, et al. 2012 investigated the methanolic extract of bark of A. hexapetalus for in vitro anthelmintic and cytotoxic activities. Brine shrimp lethality bioassay was used for the evaluation of the cytotoxic activity. The methanolic extract presented noteworthy cytotoxic potential (LC50 value of $7.688 \mu \mathrm{g} / \mathrm{ml}$ ) in comparison to standard vincristine $(0.839 \mu \mathrm{g} / \mathrm{ml})$. To evaluate anthelmintic activity where albendazole was used as the reference standard and methanolic extract of barks $(50 \mathrm{mg} / \mathrm{ml})$ showed paralysis of the worms at $68.33 \mathrm{~min}$ and death at $84.0 \mathrm{~min}$. In comparison to the standard albendazole at the concentration of $10 \mathrm{mg} / \mathrm{ml}$ worms were 
paralyzed and killed at the respective $17 \mathrm{~min}$ and $48 \mathrm{~min}$. Thus it confirmed the significant anthelmintic activities of bark extract of $A$. hexapetalus [64].

\section{Antipyretic activity}

Rahini D, et al. 2014 reported antipyretic activity of ethanolic extract of flowers of $A$. hexapetalus tested on yeast induced pyrexia in albino rats. To carry out screening of the antipyretic flower extract at oral doses of 100,250 , and $500 \mathrm{mg} / \mathrm{kg}$ was used. A significant reduction in body temperature on yeast induced pyrexia was observed at a dose of $500 \mathrm{mg} / \mathrm{kg}$ body weight when compared with standard Paracetamol drug $(200 \mathrm{mg} / \mathrm{ml})$. [65]

\section{CONCLUSION}

The present review comprises of a perspective to show current advances in the phytochemical and pharmacological activities of $A$. hexapetalus as a prognostic therapeutic agent. According to the literature review, it is uncovered that $A$. hexapetalus possesses valuable therapeutic uses as antimicrobial, antileishmanial, antioxidant, antifungal, antifertility, anthelmintic, mosquito repellent, hepatoprotective, and cytotoxic activity. It has a potent free radical scavenging property which sufficiently demonstrated in different assays. Its potential as an antioxidant and antimicrobial agent needs to be undermined in future research work. It may perhaps be advised that alkaloids, terpenoids, anthraquinones, butyrolactones, flavonoids, neolignans, phenolic compounds, and leucoanthocyanins might be valued as a principal molecule in the development of new drugs to treat various diseases. Various unique constituents in the form of flavonoids of $A$. hexapetalus can also be chemically modified or used as "lead" for developing more effective drug molecules. Therefore, extensive pharmacological and phytochemical screening, together with the pharmacokinetic and toxicological assay, will be a focus for forthcoming investigation. Furthermore, a well-designed study to measure its toxicity from its long-term use is another urgency. This review article emphasizes the potential of $A$. hexapetalus that can be employed in new therapeutic drugs and will offer the base for future research on the application of herbal medicines.

\section{ACKNOWLEDGMENT}

The authors would like to extend our gratitude to Mr. Albert W. D'Souza, Chairman Adel Education Trust and Dr.(Mrs.) Savita J. Tauro, Principal, St. John Institute of Pharmacy and Research, Palghar for the generous support, motivation, encouragement and providing necessary facilities to carry out inscription of this manuscript.

\section{AUTHORS CONTRIBUTIONS}

Abhijeet Puri: Being a single author, I carried out a compilation of literature, an inscription of a manuscript, read-through, revising, and improving the standard of the manuscript. No other co-author contributed to this work.

\section{CONFLICTS OF INTERESTS}

The authors declare that he has no conflicts of interest.

\section{REFERENCES}

1. Posluszny U, Fisher J Thorn. Hook ontogeny in Artabotrys hexapetalus (Annonaceae). Am J Bot 2000;87:1561-70.

2. Tan KK, Wiart C. Botanical descriptions, ethnomedicinal and non-medicinal uses of the genus Artabotrys r. br. Int J Curr Pharm Res 2014;6:34-40.

3. Fengxia $\mathrm{Xu}$, Louis Ronse De Craene. Floral ontogeny of Annonaceae: evidence for high variability in floral form. Ann Bot 2010;106:591-605.

4. Bhel J, Reinhard E. Natural products as medicinal agents. Stuttgart: Hippocrates Verlag 1980;227:405-30.

5. Bakshi G, Sensarma P, Pal D. A lexicon of medicinal plants in India: Regency Publication; 2006. p. 186-8.

6. Dhar U, Kachroo P. Alpine flora of kashmir himalaya scientific publishers Jodhpur; 1983. p. 132.
7. Phytoconstituents of $A$. hexapetalus. Available from: https://www.asia-medicinalplants.info/artabotryshexapetalus-l-f-bhandari/ [Last accessed on 20 Mar 2020]

8. Gupta AK, Tandon N. Reviews on Indian medicinal plants. New Delhi: Indian Council Med Res 2004;3:119,496.

9. Savithramma N, Rao L, Suhrulatha D. Screening of medicinal plants for secondary metabolites. Middle-East J Sci Res 2011;8:579-84.

10. Taxonomical Classification of Available from: https://https://plants.usda.gov/java/ClassificationServlet?sou rce=displayandclassid=ARHE11. [Last accessed on 20 Mar 2020]

11. Kirtikar K, Basu B. Indian medicinal plants. 2 ed. (Vol. 1,2,3 and 4): Dehradun: International books distributers; 1995. p. 63-4, 330-1, 1469-71, 1689-91, 2064-65.

12. Baltaev UA, Murdakhaev YM, Abubakirov NK. Phytoecdysteroids of A. lanata. Chem Nat Comp 1992;28:123-4.

13. The binomial name of $A$. hexapetulus flowers. Available from: https://www.flickr.com/photos/dinesh_valke/620673961 [Last accessed on 20 Mar 2020]

14. Vaidyaratnan PS. Varrier's Arya Vaidya Sala, Indian Medicinal Plants. 4 ed. (Vol. 1). Chennai: Orient Longman Pvt. Ltd; 2002. p. 4-6, 321-6.

15. Pullaiah T. Encyclopaedia of world medicinal plants. 5 ed. New Delhi: Daya Books; 2006. p. 214.

16. Aguilar NO. Artabotrys R. Br. ex Ker Gawl. In: Van Valkenburg $\mathrm{JLCH}$, Bunyapraphatsara N. editors. Plant resources of southeast Asia no. 12: medicinal and poisonous plants 2. Backhuys Publishers; 2001. p. 85-9.

17. Seidemann J. World spice plants: economic usage, botany, taxonomy. 4th Ed. Springer; 2005. p. 51.

18. Morphology of A. hexapetulus flowers Available from: https://http://www.efloraofgandhinagar.in/shrub/artabotryshexapetalus. [Last accessed on 20 Mar 2020]

19. Puri AV. Quantitative phytochemical screening, thin-layer chromatography analysis, high-performance thin-layer chromatography fingerprinting, and antioxidant activity of leaves of Diospyros montana (Roxb.). Asian J Pharm Clin Res 2019;12:325-31.

20. Traditional Uses of $A$. hexapetalus. Available from: http://www.pitchandikulam-

herbarium.org/contents/medicinal.php?id=36. [Last accessed on 20 Mar 2020]

21. Bajaj S, Wakode S. Standarization of A. hexapetalus. Int J Pharmacogn Phytochem Res 2016;8;398-406.

22. Khare C. Indian medicinal plants: an illustrated dictionary. Berlin: Springer-Verlag; 2008. p. 63.

23. The Wealth of India. Vol. 1-A: New Delhi: Publication and Information Directorate. CSIR; 1985. p. 513, 43.

24. Traditional Uses of $A$. hexapetalus. Available from: http://medplants.blogspot.com/2018/10/artabotryshexapetalus-champa-ylang. html. [Last accessed on 20 Mar 20]

25. Mishra S, Dwivedi S, Shashi A, Prajapati K. Ethnomedicinal uses of some plant species by ethnic and rural peoples of the Salem district of Tamilnadu with special reference to the conservation of vanishing species. Ethnobot Leaflets 2008;12:873-87.

26. Mohanty R, Tripathy B, Panda T. Role of temples and other holy places in plant conservation of Odisha, India. Int J Conserv Sci 2012;3:301-8.

27. Florence A, Joselin J, Brintha T, Sukumaran S, Jeeva S. Preliminary phytochemical studies of select members of the family Annonaceae for bioactive constituents. Biosci Discovery 2014;5:85-96.

28. Schobert R, Schlenk A. Tetramic and tetronic acids: an update on new derivatives and biological aspects. Bioorg Med Chem 2008;16:4203-21.

29. Savadi R. Phytochemical investigations and antifertility properties of some medicinal plants. Ph. D. thesis, Rajiv Gandhi University of Health Sciences; 2009.

30. Yu J, Li T, Lan L, Ding W, Li D. Neo-lignans and hemiterpenoid from the seeds of $A$. hexapetalus. J Chin Pharm Sci 2002;11:4-10. 
31. Wong H, Brown G. $\beta$-methoxy- $\gamma$-methylene- $\alpha, \beta$-unsaturated- $\gamma$ butyrolactones from $A$. hexapetalus. Phytochemistry 2002;59:99-104.

32. Yu J, Li T, Sun L, Luo X, Ding W, Li D. Chemical constituents of the seeds of A. hexapetalus. Acta. Pharm Sinica 2001;36:281-6.

33. $\mathrm{Li} \mathrm{TM}, \mathrm{Yu}$ JG. Artabotryside A, and B, two new flavonol glycosides from the leaves of Artabotrys hexapetalus (Annonaceae). Chin Chem Lett 1997;8:43-6.

34. Tong Mei Li, Wen Kui Li, Jing Guang Yu. Flavonoids from Artabotrys hexapetalus. Phytochemistry 1997;45:831-3.

35. Somanawat J, Talangsri N. Flavanoid and megastigmane glycosides from $A$. hexapetalus leaves. Biochem Syst Ecol 2012;44:124-7.

36. Feng Min Xi, Xiao Guang Chen, Yun Bao Liu, Jing Qu, Yong Li, Zhong Hai Tang, et al. Bioactive sesquiterpenoids from the roots of A. hexapetalus. Tetrahedron 2017;73:571-82.

37. Zhou Qi, Song Xiao Ping, Yan Hui, Li Fu, Xiao bao, Chen Guang Ying, et al. Bioactive benzyl isoquinoline alkaloids from $A$. hexapetalus. Phytochem Lett 2015;11:296-300.

38. Yao Xue Xue Bao. Studies on the chemical constituents of the leaves from A. hexapetalus. Acta Pharm Sinica 1998;33:591-6.

39. Singh A, Sahai M. Isolation of the flavonol glycosides from the leaves of A. odoratissimus. Planta Med 1996;62:192.

40. Phan G, Phan S, König W. Chemical composition of the flower essential oil of $A$. hexapetalus (L. f.) bhandare of vietnam. J Essent Oil Res 2007;19:523-4.

41. Mahidol C, Chimnoi N, Chokchaichamnankit D, Techasakul S. Identification of volatile constituents in A. hexapetalus flowers using simple headspace solvent-trapping technique in combination with gas chromatography-mass spectrometry and retention indices. Acta Hortic 2005;677:43-50.

42. Puri AV. Duranta repens linn. (Verbenaceae): a comprehensive review of pharmacognostic, ethnomedicinal, pharmacological, and phytochemical aspects. Asian J Pharm Clin Res 2018;11:91-6.

43. Sidhioqui N, Grag S. Analysis of the essential oils of Artabotrys odoratissimus fruits and leaves. J Sci Industrial Res 1990;33:526-37.

44. Cannolly J, Hague M, Hasan C, Haider S. Constituents of the stem bark of Artabotrys odoritissimus. Fitoterapia 1994;65:92-3.

45. Hedberg I, Hedberg O, Madati P, Mshigeni K, Mshiu E, Samuelsson G. Inventory of plants used in traditional medicine in Tanzania. I. Plants of the families AcanthaceaeCucurbitaceae. J Ethnopharmacol 1982;6:29-60.

46. Li TM, Li WK, Yu JG. Flavonoids from A. hexapetalus. Phytochem 1997;45:831-3.

47. Chuakul W, Soonthornchareonnon N. Ethnomedical uses of thai Annonaceous plant. Thai J Phytopharm 2003;10:25-32.

48. Aguilar NO. Artabotrys R. Br. ex ker gawl. In: Van Valkenburg JLCH, Bunyapraphatsara N. editors. Plant resources of SouthEast Asia no. 12: medicinal and poisonous plants 2. Backhuys Publishers; 2001. p. 85-9.

49. Lal H, Singh S. Study of plant biodiversity of Hazaribag district Jharkhand India and its medicinal uses. Biosci Discovery 2012;3:91-6.
50. Dhiman A, Singh D, Bala M, Sharma K. Potential phytotherapeutic agents in the design of ethosomes: a review. J Pharm Sci Innov 2012;1:26-30.

51. Rajkumar M, Rajanna M. Ex-situ conservation of climbing plants at the university of agricultural sciences, Bangalore, Karnataka. Recent Res Sci Technol 2011;3:18-20.

52. Shankar P, Ananthi P, Basker S. Phytochemical screening and antibacterial efficacy of $A$. hexapetalus. Res Plant Biol 2015;5:10-3.

53. Sowjanya K, Swathi J, Narendra K, Padmavathi C, Satya A. Extraction and antimicrobial potential of secondary plant metabolites from A. hexapetalus (Linn. F.) Bhandari. Int J Res Ayurveda Pharm 2013;4:764-8.

54. Grainge $\mathrm{M}$, Alvarez A. Antibacterial and antifungal activity of $A$. hexapetalus leaf extracts. Int J Trop Plant Diseases 1987;5:173-9.

55. Haseena S, Shanavas S, Duraimurugan J, Ahamad T, Alshehri S, Acevedo $\mathrm{R}$, et al., Investigation on photocatalytic and antibacterial ability of green treated copper oxide nanoparticles using A. hexapetalus and Bambusa vulgaris plant extract. Mater Res Express 2019;6:5064.

56. Bajaj S, Wakode S, Khan W, Manchanda S, Kumar S. Simultaneous HPTLC analysis and in vitro antileishmanic activity of various secondary metabolites in an extract of the traditional medicinal herb A. hexapetalus (L. f.). Ayu 2018;39:92-100.

57. Manjula M, Kumuda K, Anitha S, Shashidhara S. Antioxidant and antimicrobial activities of various extracts of $A$. hexapetalus flowers. Int J Pharm Sci 2011;3:S-42-50.

58. Satya A, Sowjanya K, Swathi J, Narendra K. Estimation of in vitro antioxidant activity and total phenolic, flavonoid content of selected medicinal plants. Int J Pharm Sci Rev Res 2017;43:142-7.

59. Rahini D, Anuradha R. In vitro antioxidant activity of $A$. hexapetalus. Res J Pharm Biol Chem Sci 2014;5:396-405.

60. Bollapragada M, Shantaram M. Comparative phytochemical profiles and antioxidant properties of Antigonon leptopus, Artabotrys hexapetalus and Allamanda blanchetii leaf extracts. Int J Pharmacogn Phytochem Res 2018;10;327-33.

61. Rajabu A Suleiman, Quitino A Mgani, Stephen S Nyandoro. Chemical compositions and mosquito repellency of essential oils from $A$. hexapetalus and A. rupestris. Int J Biol Chem Sci 2014;8:2804-12.

62. Karthik Y, Vrushabendra Swamy B, Vishwanath K. Evaluation of anti-fertility activities of leaves of $A$. Hexapetalus (Linn. F). Res J Pharm Biol Chem Sci 2012;3:1121-34.

63. Veena Rani I, Annapurna A, Ganapathi S. Evaluation of hepatoprotective activity and oxidative stress parameters of alcoholic extract of $A$. hexapetalus (l. f) bhandari. J Global Trends Pharm Sci 2016;7:3192-9.

64. Morshed N, Moghal R, Amin N, Md Kibria G, Dewan R. Investigation of in vitro anthelmintic and cytotoxic activities of A. hexapetalus (family: Annonaceae) bark growing in Bangladesh. Trend Biotechnol Res 2012;1:27-30.

65. Rahini D, Anuradha R. Antipyretic activity of A. hexapetallus flower extract. Am J Pharm Health Res 2014;2:66-71.

66. Wijesekera R. The medicinal plant industry CRC press. 1st Ed. Taylor Francis New York; 1991. p. 175. 